\title{
Exploring Possibilities to Enhance Food Sovereignty within the Cowpea Production-Consumption Network in Northern Ghana
}

\author{
Wilhelmina Quaye*1, Godfred Frempong ${ }^{2}$, Joost Jongerden ${ }^{3}$ and Guido Ruivenkamp ${ }^{3}$ \\ ${ }^{1}$ Food Research Institute (CSIR) Box M20, Accra/CTC Wageningen University, Wageningen, \\ The Netherlands \\ ${ }^{2}$ Science and Technology Policy Research Institute (CSIR) Box CT519 and ${ }^{3}$ Social Science \\ group/CTC Wageningen Universit, Wageningen, The Netherlands
}

KEYWORDS Empower. Local. Food. Production. Consumption

\begin{abstract}
Over the last years an important focus in the combat of hunger and malnutrition, particularly in Africa has been food security. This article explores possibilities for enhancing food sovereignty, as an alternative concept to food security and an alternative strategy for reversing hunger and malnutrition trends in developing countries. A combination of literature review, participatory appraisal and conventional survey methodologies are used to investigate the relevance of local cowpea (Vigna unguiculata) network regarding its importance vis-à-vis other crops, varietal choice, and consumption patterns in Northern Ghana from food sovereignty perspective. Findings reveal how people in poverty-stricken and hunger- hot- spot communities strive to conserve their bio-diversity and productionconsumption networks for posterity. Local cowpea varietal preferences are investigated for participatory breeding considerations to improve on seed access for sustainable production. Promotion of origin-based foods in the current fast growing globalised markets is recommended as a possibility to enhance food sovereignty for sustainable development in Africa
\end{abstract}

\section{INTRODUCTION}

\subsection{The Problem}

The current global market has not lead to safe and healthy foods, and does not ensure equitable access to food (IFPRI 2008). The situation is worsening with the high food prices that is putting at risk the development potential of millions of people. Large numbers of people continue to suffer acute hunger and poverty in developing countries despite the implemention of conventional food policies through several developmet efforts (IFPRI 2007; UNDP 2005; FAO 2003). Globalisation (a process of increasing integration of nations worldwide) has resulted in disconnections of agriculture and environment, agriculture and food as well as agricultural products from their intrinsic nutritional quality (Ruivenkamp 2005). In a developing country like Ghana, food production and consumption are interlinked in local networks that are usually located in rural areas where the incidences of food insecurity, poverty and malnutrition are particularly devastating. Farmers, processors and consumers in the local networks live in rainfed

*Corresponding Author:

E-mail: quayewilhemina@yahoo.com smallholder farming areas and have often been bypassed by green revolution and its related market opportunities. Small holder farmers, processors and consumers in developing countries often cannot access or afford technological products, and the products are often not adapted and attuned to risk-prone subsistence networks (Roling 2008; Oxfam 2008).

Reflecting on the persistent poverty and malnutrition situation particularly in developing countries, there is the need to reconsider alternative approaches to research and development. The challenge is to search for developmental potentialities within the local context. Instead of adapting local resources to proposed global solutions a reversed innovation trajectory is proposed which starts from the strengths of the local, natural and social resources. Out of this new paradigm of endogenous developments or developments from within, having control over local, natural and social resources is born the concept of food sovereignty.

\subsection{Food Sovereignty Concept: Bottom-Up Approach to Sustainable Development}

Food sovereignty is the right of people and communities to decide and implement their agricultural food policies and strategies for 
sustainable production and distribution of food. It is the right to access productive resources such as land, water, seeds and bio-diversity, right to produce food sustainably and ecologically, access to market and the right to adequate, safe, nutritional and culturally appropriate food (People's Food Sovereignty Network July 2004). Food sovereignty, although an infant concept, has attracted a lot of attention in development agenda setting discourse in recent times. It is described as a bottom-up approach to sustainable development in the literature (Altieri 2002; Windfuhr 2005; Collier 2007; Quaye 2007).

From food sovereignty perspective, farmers have the right to produce what they want to consume instead of relying on conventional food supply chains that dwell mostly on comparative advantage, an option for the economically efficient. There are a lot of arguments in favor of food sovereignty development approaches. For example Pimbert (2006) proposed a radical shift away from the existing top-down and increasing corporate controlled research system to an approach which devolves more responsibility and decision-making power to farmers, indigenous people, food workers, consumers and citizens. Thus democratizing science and technology research in search for locally adapted solutions enhance food sovereignty and create enabling context for social learning and actions. As suggested by Olutayo and Omobowale (2007) the way out of underdevelopment is for developing world to control and own their means of survival. Similarly, Mazhar et al. (2007) explored the meaning of agriculture in relation to the convergence of food, ecology, and culture from food sovereignty perspectives. He demonstrated the value of food production and consumption systems that are localized rather than globalized in South Asia. In this context, food sovereignty is described as the conservation of biological diversity and revitalization of ethical community relations as well as cultural politics of food. McAfee (2008) also explained contrasting food system paradigms, agricultural modernization, export competition, and food import dependence versus an alternative vision of revitalized rural life, farmers' rights, and national food sovereignty in Mexico.

In contrast to food sovereignty, food security is defined as physical and economic access to sufficient food by all people at all times to meet their dietary needs in order to lead a healthy and productive life (FAO 2002). The key difference between food sovereignty and food security is the means of accessing food. While food is seen as a tradable commodity that can be produced anywhere and any how under food security, with food sovereignty food should be healthy, culturally appropriate and locally produced if resources allow. Therefore from food sovereignty perspective, rural communities need to be empowered to produce using agro-ecological, sustainable farming methods instead of industrial, monoculture and chemical intensive farming methods used to achieve food security. Food sovereignty is a precondition to 'genuine food security' and the right to food is considered as a tool to achieve it (Rosset 2006a).

\subsection{Why Local Cowpea Network and Northern Ghana?}

Cowpea (Vignaunguiculata(L)Walp) is a major grain legume in Sub-Sahara Africa. The cowpea network is chosen as the reference crop for this study because of its socio-economic and socio-cultural significance in the local production, processing and consumption patterns (Langyintuo et al. 2003 and Langyintuo et al. 2004). Most farmers intercrop cowpea with other crops due to its nitrogen fixation capacity for soil improvement, commercial and domestic purposes. Other considerations are incomes to small-scale processors and its nutritive value when the micronutrients availability is enhanced. Cowpea is widely consumed in Ghana with cereals like rice (waakye) as well as other popular staples like processed cassava (gari), yams and ripe plantains. Cowpea has a social-nutritionally defined role and could be strategically used to demonstrate the reconnection of agriculture to the local environment; the reconnection of consumers to locally produced healthy foods; and reconnection of farmers to productive resources such as locally improved seeds which are prerequisite for food sovereignty. Northern Region is one of the poverty-stricken and hungerhot-spots in Ghana. It is a popular area for cowpea production as well as consumption and can be conveniently used to better understand food sovereignty issues.

A network is a set of relationships that can be categorized into three, though interrelated both in space and time; those in the immediate surrounding (unit), those who negotiate 
(brokers) and those at a distance (boundary spanners) but well positioned in connection with institutions at local, national and international spheres (Lockie 2004). As employed by (Raynolds 2004) relations between network actors, the social composition, their roles, power relations need to be understood to be able to identify actualities and potentialities within the local food network for re-designing better locally acceptable technologies. This paper does not present strong analytical underpinning on network analysis. However cowpea production, processing and consumption in the local communities surveyed could be best described as a network. The producers are also consumers and in some cases processors as well. The survey presents data mainly on key actors such as farmers, processors and consumers but very little is mentioned on researchers, extension agents, input suppliers and other actors who are also in the cowpea network.

\section{OBJECTIVES AND METHODOLOGY}

\subsection{Objectives}

The specific objectives of this study were as follows;

- To investigate the social relevance of cowpea production in relation to varietal choice and consumption pattern

- To explore the possibilities for enhancing food sovereignty within the cowpea production-consumption network for sustainable development

\subsection{Methodology}

As mentioned in the introduction, literature review is supported with findings from a survey conducted in Tolon Kumbungu district of Northern Ghana in August 2007.

\subsubsection{Survey Area}

Tolon Kumbungu district is in the Northern Region, which is one of the poorest regions in Ghana (GLSS 2000). The district has estimated population of 135,081 based on the 2000 population census and population growth rate of $3.5 \%$ per annum. The population is basically rural with the farming population making up to $90 \%$. The average household size is 14 ; far higher than the national average probably due to the use of family labour on farms. The district covers a land area of nearly $2,400 \mathrm{~km}^{2}$ with only about a little more than one half of it being under crop cultivation. Major food crops grown in the District are: cereals (maize, rice, sorghum and millet), root and tubers (cassava, yam and Potatoes), legumes (groundnut, cowpea, soybean, pigeon pea and bambara beans), vegetables (okro, tomatoes, pepper, onions, garden eggs, leafy vegetables) and fruits (cashew, mangoes, water melon, shea fruits).

\subsubsection{Survey Methods}

The under-listed survey methods were employed:

- Focus group discussions using an interview guide/checklist

Participatory appraisal and semi-structured interviews with key Informants including local people who have adequate information on indigenous knowledge, traders, chiefs and community assembly members.

- Conventional survey method using questionnaire for structured interviews with appropriate representation of target groups; farmers, consumers and processors.

\subsubsection{Sampling Technique and Data Collection}

A snowball sampling technique was used to locate key informants who have adequate knowledge about the cowpea network regarding production, farming practices, processing, consumption pattern, and possibilities for enhancing food sovereignty. Stratified random sampling was also used to provide appropriate representation of subgroups (farmers, processors and consumers) in the population. Actual Sample size was based on the population of selected communities and availability of resources. A total of 100 people were interviewed consisting of 30 farmers, 30 consumers, 30 key informants and 10 processors in Tibung, Wantigu, Nyamkpala, Gbanlilugu and Kpaligum all in Tolon- Kumbungu District.

\section{RESULTS}

Results obtained from field data (on cowpea production, processing and consumption) is presented in this section for more in-depth discussion on possibilities for enhancing food 
sovereignty later. The section is structured into five main subheadings including, demographic profile of respondents, relative importance of cowpea, varietal choice and seed exchange as well as cowpea processing and consumption.

\subsection{Demographic Profile of Respondents}

There is social division of labour in cowpea production and processing. The cultivation was largely done by men with approximately $97 \%$ of the farmers interviewed being males while the processing activity was exclusively carried out by women. Both men and women consume cowpea based foods. Table1 presents a summary of the demographic profile of the farmers, processors and consumers interviewed.

In terms of education, approximately $14 \%$ of farmers interviewed had formal education up to primary school level, while the rest had no formal education. All the processors interviewed had no

Table 1: Demographic profile of respondents

\begin{tabular}{|c|c|c|c|}
\hline Characteristics & Farmers & $\begin{array}{c}\text { Proce- } \\
\text { ssors }\end{array}$ & $\begin{array}{c}\text { Consu- } \\
\text { mers }\end{array}$ \\
\hline \multicolumn{4}{|l|}{ Sex } \\
\hline Male & $96.60 \%$ & - & $34.50 \%$ \\
\hline Female & $3.40 \%$ & $100 \%$ & $65.50 \%$ \\
\hline \multicolumn{4}{|l|}{ Age (Years) } \\
\hline Minimum & 18 & 20 & $\mathrm{NA}^{\mathrm{ii}}$ \\
\hline Mean & 40 & 31 & NA \\
\hline Maximum & 80 & 50 & NA \\
\hline \multicolumn{4}{|l|}{ Educational Level } \\
\hline No Education & $86.20 \%$ & $100 \%$ & NA \\
\hline $\begin{array}{l}\text { Primary Education } \\
\text { Religion }\end{array}$ & $13.80 \%$ & - & NA \\
\hline Moslem & $93.10 \%$ & $100 \%$ & NA \\
\hline Traditionalist & $6.90 \%$ & - & NA \\
\hline \multicolumn{4}{|l|}{ Marital Status } \\
\hline Married & $89.70 \%$ & $88.90 \%$ & NA \\
\hline Single & $10.30 \%$ & - & NA \\
\hline Widowed & - & $11.10 \%$ & NA \\
\hline \multicolumn{4}{|l|}{ Household Size } \\
\hline Minimum & 4 & 5 & NA \\
\hline Mean & 14 & 10 & NA \\
\hline Maximum & 20 & 23 & NA \\
\hline Main Occupation & $93.10 \%$ & $11.10 \%$ & $55.20 \%$ \\
\hline Farming & - & - & $13.80 \%$ \\
\hline Trading & - & $88.90 \%$ & $3.40 \%$ \\
\hline Processing & $6.90 \%$ & - & - \\
\hline Salary worker & - & - & $13.80 \%$ \\
\hline Food Vending & - & - & $3.40 \%$ \\
\hline Seamstress & - & - & $10.30 \%$ \\
\hline Housewives & & & \\
\hline \multicolumn{4}{|l|}{ Secondary Occupation } \\
\hline Farming & $3.40 \%$ & $42.90 \%$ & NA \\
\hline Trading & $37.90 \%$ & $42.90 \%$ & NA \\
\hline Processing & - & $14.20 \%$ & NA \\
\hline Others & $58.60 \%$ & - & NA \\
\hline
\end{tabular}

formal education. Average household size of farmers and processors interviewed were 14 and 10 respectively. Approximately, $7 \%$ of farmers interviewed were salary workers and the rest had their main source of household income from farming activity. Therefore any improvement in their farming practices could go along way to improve their livelihoods.

Cowpea processing was the main source of income for the majority $(89 \%)$ of processors interviewed while $11 \%$ were also farmers. Income generating activities of consumers interviewed were variable; farming (55\%), trading (14\%), food vending $(14 \%)$, housewives $(10 \%)$ and sewing $(3 \%)$.

\subsection{Relative Importance of Cowpea Vis-À-Vis Other Crops Grown}

Cowpea is an important component of sustainable cropping system in Tolon Kumbungu district of Ghana. It is cultivated for the leaves, green pods, grain and haulm for livestock feed. The crop is drought tolerant, fixes nitrogen up to $240 \mathrm{~kg} / \mathrm{ha}$ and leaves about 60 $70 \mathrm{~kg}$ nitrogen for succeeding crops (MOFA 2005). Thus rotating or intercropping cowpea with other crops contributes to improving soil fertility. Responses on the relative importance of crops grown in terms of income and food security are presented in tables 2 and 3 .

Among major crops grown in Tolon Kumbungu District such as groundnut, rice, cowpea, maize and yam, cowpea was ranked third

Table 2: Relative importance of crops grown in terms of income

\begin{tabular}{llc}
\hline Ranking & Crop & $\%$ Respondents \\
\hline $1^{\text {st }}$ Ranking & Groundnut & 46.4 \\
$2^{\text {nd }}$ Ranking & Rice & 33.3 \\
$3^{\text {rd }}$ Ranking & Cowpea & 50.0 \\
$4^{\text {th }}$ Ranking & Maize & 31.8 \\
$5^{\text {th }}$ Ranking & yam & 27.3 \\
\hline
\end{tabular}

Source: Survey findings August. 2007

Table 3: Relative importance of Cowpea in terms of household food provision

\begin{tabular}{llc}
\hline Ranking & Crop & \% Respondents \\
\hline $1^{\text {st }}$ Ranking & Maize & 93.2 \\
$2^{\text {nd }}$ Ranking & Yam & 39.3 \\
$3^{\text {rd }}$ Ranking & Cowpea & 42.9 \\
$4^{\text {th }}$ Ranking & Rice & 26.1 \\
$5^{\text {th }}$ Ranking & Sorghum & 7.1 \\
\hline \multicolumn{2}{l}{ Source: Survey findings August. 2007 }
\end{tabular}


in terms of household income generation and household food provision by $50 \%$ and $43 \%$ of farmers interviewed respectively. Groundnut was ranked first in terms of household income generation while maize was the most important for household food provision. Again in terms of land resource allocation, cowpea was the third most important crop. The average farm size of cowpea cultivation in the survey area was approximately 0.6 hactares. Figure 1 depicts the average farm sizes of crops grown. The uniqueness of cowpea as a source of household food is its availability during hunger seasons ${ }^{1}$ especially, the early maturing varieties.

\subsection{Cowpea Varietal Choice and Seed Exchange}

Farmers in the survey area cultivated both improved and local varieties. Improved varieties are high yielding, erect, less tolerant to insects and have low storability. Seed Coat could either be white or red. Examples of improved varieties cultivated are Akpaagbala, Marfo-Tuya, Vallenga and Bengpla. Approximately, 22\% of the farmers interviewed cultivated solely improved varieties for commercial purposes, $32 \%$ cultivated only local varieties while $46 \%$ cultivated both local and improved varieties (See Fig. 2). Local varieties are low yielding, creepy but are tolerant to insects and have high storability. Examples of local varieties are sanze zee, sanze peli and sanze sabli. Farmers showed preference for early- maturing local cowpea varieties that are insect tolerance and give relatively better yields with very little agrochemical applications

Sources of cowpea seeds for planting include market/traders, stored seed from own farm and from other farmers who preserve seeds for sale (ash is used to preserve seeds). As shown in figure 3, more than half of the farmers interviewed sourced planting seeds from their own farms/farmers. In the absence of community owned gene banks these farmers took it upon themselves to conserve biodiversity as cultural legacy of the community and also as a means to sustain their livelihoods. The local farmers are concerned about biodiversity farming systems and ecological sustainability. Farmers/producers who are themselves consumers showed commitment to ready access to productive resources notably seeds.

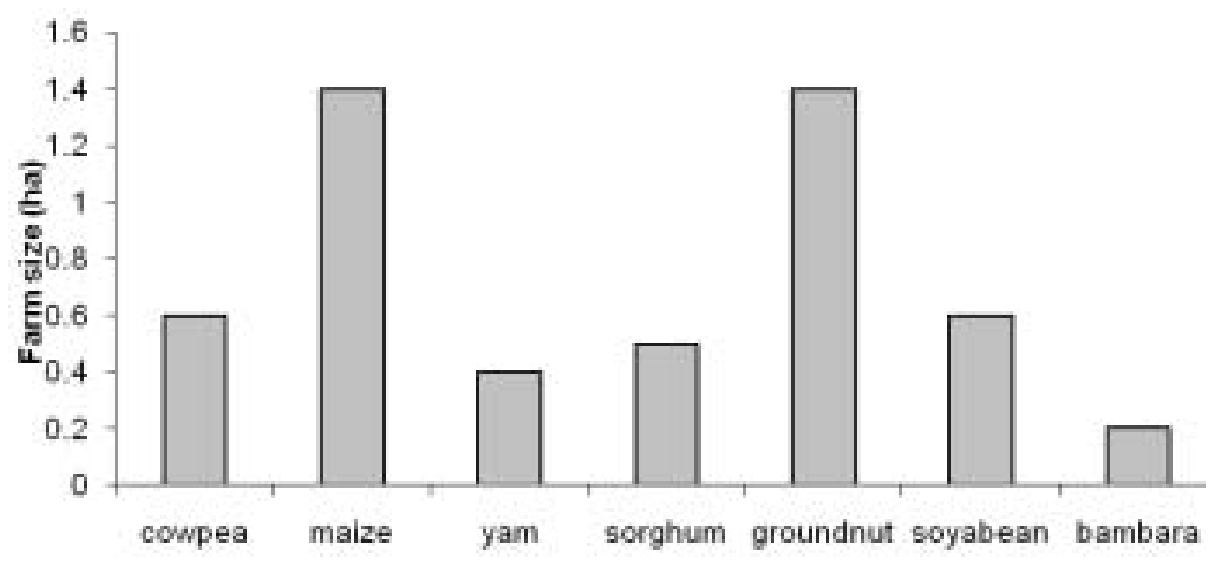

Fig. 1. Average farm size of crops ground in the study comments

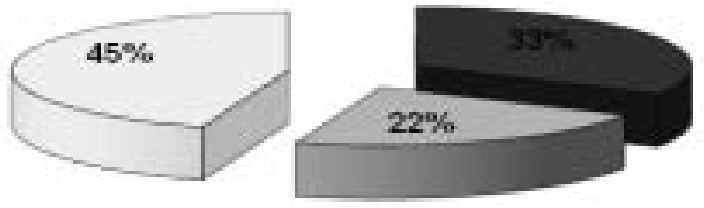

a Local

Q Improvied

c Both

Fig. 2. Varieties of cowpea grown by respondents 


\subsection{Cowpea Processing}

The raw cowpea beans are sorted, soaked and milled to obtain the flour for various food preparations. For example, water is added to cowpea flour, whipped, shaped into balls and deep fried into 'koose'. It was revealed that women are the custodians of the traditional processing technologies (indigenous knowledge). Such indigenous knowledge is passed on to generations through learning by doing - apprenticeship in an informal manner. Every female child learns as she assists the mother on the job. This way the capacity to process cowpea for home consumption and sale as street food have been ingrained in the society. From the processors interviewed popular commercial cowpea based products in the communities visited are 'Gable, Tubani, waakye, koose and boiled cowpea beans. The main cowpea processing constraint mentioned by respondents is the long cooking hours. To reduce the long cooking hours, salt peter is added. This also lessens flatulence associated with cowpea consumption.

Cowpea processors in the communities visited sourced significant proportion $(67 \%)$ of raw materials (Cowpea) from the locality. This

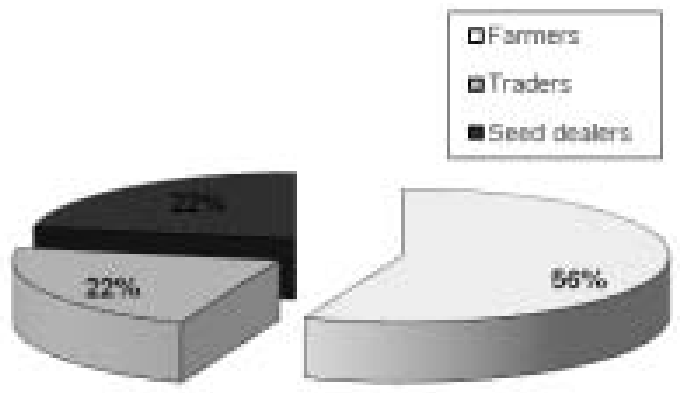

Fig. 3 Sources of cowpea seeds for planting provides credence for the definition of the food sovereignty concept. Again this suggests the potentiality of using food sovereignty concept as a tool to improve livelihoods in rural economies. The processors confirmed that cowpea is available throughout the year especially at the major market centers although prices change to reflect demand and supply conditions. Peak and lean seasons are October-November and JulyAugust respectively

\subsection{Cowpea Consumption Patterns}

Cowpea has diversified food uses. Philip et al. (2003) mentioned over 50 different dishes of cowpea in both whole grain and milled forms. Foods prepared from cowpea in Tolon Kumbungu district include leaves for stew, weaning foods/ porridge, gari and beans, waakye and koose. Others are gable, nyonbeeka, tubani, gora, apprepensa and nagbechinge (maize and beans). Table 4 presents frequency of consumption of popular cowpea based foods in the Tolon Kumbungu District while Figures 4 and 5 compare the past (last 5 years) and current frequency of consumption. A weighted average based on a score of 1-7; 1 for least consumed and 7 for most consumed was used to investigate cowpea consumption shifts in Tolon Kumbungu District.

\section{DISCUSSIONS}

Discussions of survey findings have been structured based on production and consumption issues and possibilities for enhancing food sovereignty.

\subsection{Local Production and Food Sovereignty}

From food sovereignty perspective, farmers

Table 4: Frequency of consumption of Cowpea based foods in the study communities

\begin{tabular}{lccccccc}
\hline \multirow{2}{*}{$\begin{array}{l}\text { Type of } \\
\text { product }\end{array}$} & \multicolumn{7}{c}{ Frequency of consumption per week } \\
\cline { 2 - 8 } & Once & Twice & Thrice & Four Times & Five Times & Six Times & Seven Times \\
\hline Gable & 7.7 & 30.8 & 19.2 & 23.1 & - & 3.8 & 15.4 \\
Koose & 33.3 & 16.7 & 11.1 & 11.1 & - & - & 27.8 \\
Waakye & 14.3 & 28.6 & 23.8 & 23.8 & - & - & - \\
Tubani & 29.2 & 37.5 & 20.8 & 12.5 & - & - & - \\
Nyonbeka & - & - & 16.7 & - & - & - & - \\
Gora & - & - & - & - & - & - & - \\
*Apprepresa & 33.3 & 33.3 & 33.3 & - & - & - \\
*Tombrown & - & 33.3 & - & - & - & - \\
\hline
\end{tabular}

* Consumption largely by kids, koose and to a lesser extent waakye are consumed as street foods 

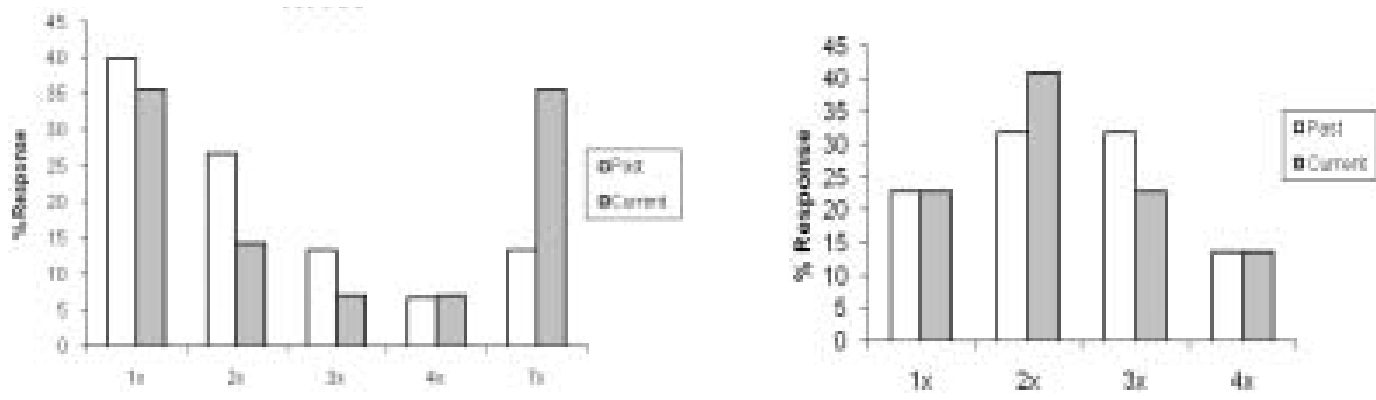

Fig. 4. Past Vs Current consumption-frequency of Koose and Tubani
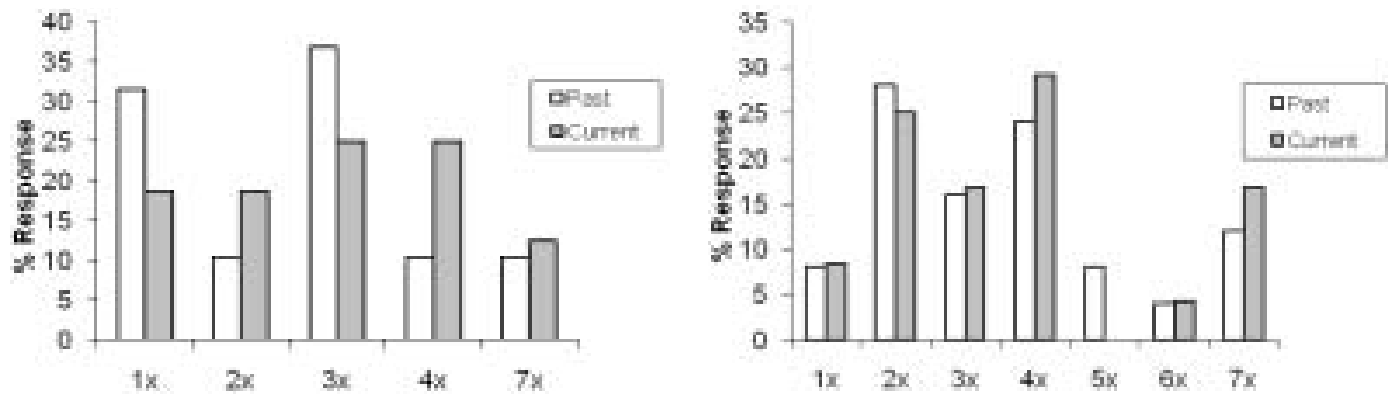

Fig. 5. Past Vs Current consumption -frequency of Waakye and Gable

in the local cowpea network made the effort to produce what they want to consume. Almost all the crops produced were also consumed in the localities. Food was seen as a commodity to be consumed before considering it as tradable in the cowpea network surveyed. Farmers who were themselves consumers and sometimes processors cultivated most of their staple foods as a 'survival strategy' or what could be termed as 'food sovereignty strategy'. Majority of the farmers were cultivating at the small scale level with average farm size of approximately 0.6 hectares of cowpea. In terms of income generation, approximately 93 per cent of respondents in the cowpea network had their main source of household income from farming activity. As explained earlier farmers cultivated cowpea not just for income and food provisioning but as an important component of sustainable cropping system and soil fertility improvement in the area.

The above observation gives credence to the fact that small scale farmers aim to live in relative harmony with the natural environment and should be empowered to produce instead of crowding them out of their jobs with 'globalized markets'
(Manzini 2005; Rosset 2008). Being able to produce for domestic consumption needs is more of a right issue and gives local people a life with dignity. A similar desire of local people having control over their natural and social resources has been observed by Ramakrishan (2008) in India. He proposed tailor-made solutions to sustainable agriculture which allow participation of local people in the developmental process. Having so empowered, these societies can move along a trajectory for development which is in harmony within the given socio-ecological system that they chose for themselves.

Again from survey results, 33 per cent of the respondents cultivated only local varieties for home consumption while 45 percent cultivated both improved and local seeds. High preference for local varieties was due to their peculiar characteristics as explained earlier and farmers were determined to conserve their local seeds. Preference for local varieties especially the early maturing ones has food sovereignty implications. The early maturing local varieties are harvested before any other crops to meet food requirements of the households during hunger periods. Women 
farmers cited another advantage of local varieties as being that they are never sprayed and therefore the leaves can be consumed, providing an important source of vitamins and iron. The farmers who used improved seed (about $22 \%$ of farmers interviewed cultivated improved seed for commercial purposes) depended on certified seed growers and sellers due to loss of hybrid vigor. The issue of over-reliance on the seed industry and agrochemical dealers has become a serious concern by small scale farmers because of cost implications. Although for grains and legumes and cowpea in particular, the role of seed growers associations is to facilitate seed supply to farmers, they have profit motives and therefore improved seeds have become very costly to the average small-scale farmer. Local varieties although have poor yields are self pollinating and require less or virtually no external capital intensive inputs like fertilization and application of other agrochemicals. Farmers put it bluntly that under harsh environmental conditions local varieties perform better than improved varieties.

Autonomy in access to seeds is crucial in terms of enhancing food sovereignty. The survival strategies of the very poor and the ongoing contribution of biodiversity to livelihoods are clearly demonstrated. With ever increasing seed cost implications, farmers cannot buy seeds for planting each year (over-reliance on the seed industry); especially when they are convinced that seeds can be preserved locally. The farmers do not want to be disconnected from their traditional roles of seed production. This supports the argument by Rosset (2006b) that seed as a productive resource has to be a common heritage of humanity, held in trust by communities instead of seed being a patentable commodity. The food sovereignty framework empowers local people to take control over their productive resources. Therefore, it is important farmers play indispensable role in seed development activities (Vernooy 2003).

\subsection{Local Consumption Pattern and Food Sovereignty}

Cowpea consumption patterns of the communities surveyed have not changed much over the years. The survey results show no significant change in past consumption patterns of gable and tubani, which are the most common home prepared cowpea products, as compared to their current situation. There is however a significant increase in the consumption of koose which is considered as street food. Consumption of 'waakye' increased slightly and most importantly more as street food than home prepared food. The positive change in consumption patterns of koose and waakye as street foods could be partly explained by the community's effort to integrate local and originbased food products into the fast growing globalised food chain. From food sovereignty perspective, having origin-based foods integrated into global food chains as street foods competing with foreign food products help prevent loss of traditional food culture.

\subsection{Possibilities for Enhancing Food Sovereignty}

Two clear possibilities can be identified from survey findings. Firstly, farmers showed preference for early maturing local cowpea varieties that were insect tolerance and gave relatively better yields with very little agro-chemical applications. Such varietal charac-teristics need to be considered in participatory breeding efforts. Farmers must be empowered to produce their own seeds and conserve bio-diversity. This will go along way to improve farmers' access to seed which is an important productive resource and therefore can enhance food sovereignty.

Secondly, it is possible to promote originbased foods in the current fast growing globalised markets. Local food producers and processors can be helped to regain their control to access market and similarly consumers encouraged to have access to culturally accepted nutritious foods. Improving the nutritive qualities of waakye and koose can therefore enhance food sovereignty. Exploiting added advantage of unique taste for local cowpea based foods; these products can be used to demonstrate reconnection of agricultural products to local consumption patterns. Food has a social dynamic dimensions, it is a basic human right which must be healthy, culturally appropriate and locally accepteble

\section{CONCLUSION}

This article investigates the social relevance of cowpea network with regards to the importance of cowpea cultivation vis-à-vis other crops, varietal choice, and consumption patterns in Northern Ghana from food sovereignty pers-pective. Using 
exploratory survey methods, findings from the cowpea production-consumption network revealed that there are possibilities for enhancing food sovereignty in local communities. Cowpea producers showed high preference for local varietal characteristics which need to be considered in participatory breeding efforts to improve access to productive resources. Integration of originbased food products into global food chains as street-foods will create market for local people. With soaring food prices there is no doubt that hunger and malnutrition trends in developing countries can only be reversed through improved and sustainable local production. It is possible to achieve food self-sufficiency in local communities in developing countries if resource allocation is equitable because the people are committed as demonstrated in the cowpea productionconsumption network.

\section{NOTES}

i Hunger Season is the period between planting and the next harvest; February/March-July/August

ii The questionnaire designed for consumers was brief and did not include most biodata

\section{REFERENCES}

Altieri MA 2002. Agroecology: The Science of Natural Resources Management for Poor Farmers in Marginal Environments. Agriculture, Ecosystems and Environment, 1971: 1-24.

Collier P 2007. The Bottom Billion: Why the Poorest Countries Are Failing and What Can Be Done About It. Oxford: Oxford University Press, P. 3.

FAO 2006. The State of Food and Agriculture. Rome, Italy: Food and Agricultural Organization of the United Nations (FAO).

FAO 2002. The State of Food Insecurity in the World 2001. Rome, Italy Food and Agriculture Organization (FAO), pp. 4-7.

IFPRI 2008. High Global food Prices: The Challenges and Opportunities. Washington DC: International Food Policy Research Institute (IFPRI) 2007-2008 Annual Report Essay, September 2008.

IFPRI 2007. Sustainable Solutions for Ending Hunger and Poverty: The Future of Small Farms for Poverty Reduction and Growth. Washington DC: International Food Policy Research Institute (IFPRI) Vision 2020 Policy Briefs, May 2007.

Langyintuo AS, Lowenberg-DeBoer J, Faye M, Lambert D, Ibro G et al 2003. Cowpea Supply and Demand in West and Central Africa. Field Crops Research, 82: 215-231.

Langyintuo AS, Ntoukan G, Murdock L, LowenbergDeBoer J, Miller DJ 2004. Consumer Preferences for cowpea in Cameroon and Ghana. Journal of Agricultural Economics, 30: 203-213.
Lockie S 2004. Networks of Agri-environmental Action: Temporality, Spatiality and Identity in Agricultural Environments. Sociologia Ruralis, 46(1): 22-39.

Mazhar F, Buckles D, Satheesh PV, Akhter F 2007. Food Sovereignty and Uncultivated Biodiversity in South Asia: Essay on the Poverty of Food Policy and the Wealth of the Social Landscape. Policy Research for Development Alternatives, Dhaka Bangladesh 2007 New Delhi: Academic Foundation.

McAfee K 2008. Beyound Techno-science: Transgenic Maize in the Fight Over Mexico's Future. Oxford: Elsevier 39(1): 148-160.

Manzini E 2005. New food networks: Agriculture, Food and Design for a Multi-local World. Tailoring Biotechnologies, 1(2): 65-80.

MOFA 2005. Food Crops Development Project Report. Ghana: Ministry of Food and Agriculture.

Olutayo AO, Omobowale AO 2007. Capitalism, Globalisation and the Underdevelopment Process in Africa History in Perpetuity. Africa Development, 32(2): 97-112.

Oxfam 2008. Partnership or Power Play? How Europe should bring development into its trade deals with African, Caribbean, and Pacific Countries. Policy Paper 2008, Oxford, UK: Oxfam International.

People's Food Sovereignty Network 2004. Beijing Declaration from NGO/CSO Regional Consultation: From Agenda to Action' Follow-up to the NGO/ CSO Forum for Food Sovereignty. www.peoplesfood sovereignty.org/statements/new/23.htm.

Philip RD, McWalters KH, Chinnan MS, Hung Y, LR Benchat et al 2003. Utilisation of cowpea for human food. Science Direct Field Crops, 82 (2): 193-213.

Pimbert M 2006. Transforming Knowledge and Ways of Knowing for Food Sovereignty. Published by The International Institute for Environment and Development (IIED) 2006, Endsleigh Street, London UK.

Quaye W 2007. Food Sovereignty and combating poverty and Hunger in Ghana. Tailoring Biotechnologies 3(2):101-108.

Ramakrishnan PS 2001. Ecology and Sustainable Development. New Delhi: National Book Trust of India.

Ramakrishnan PS 2008. Ecology and Sustainable Development: Role of Knowledge Systems. New Delhi: National Book Trust of India. 198 pp.

Raynolds LT 2004. The globalization of organic agrifood networks World Development 32(5): 725-743.

Rosset P 2008. Food sovereignty and the contemporary food crisis. World Development, 51(4): 460-463.

Rosset P 2006a. Global rallying Cry of Farmer Movements, Food First. Policy Brief Vol 9, No. 4.

Rosset P 2006b. Agrarian Reforms and Food Sovereignty: Alternative Model for the Rural World. A paper presented at 55 th Annual Conference of the Center for Latin American Studies at the University of Florida, USA, February 23-25, 2006.

Roling N 2008. The Future of Food and Farming: Complexity Thinking and Social Development. The Broker Issue 7, April 2008 www.thebrokeronline.eu

Ruivenkamp G 2005. Between Bio-Power and SubPolitics. Tailoring Biotechnologies 1(1): 11-32. 
UNDP 2005. Millennium Project 2005. United Nations Development Program (UNDP). Final Report of the Task Force on Hunger. New York: UNDP.

United Nations Development Program (UNDP) 2005. Millennium Development Goals Report 2005, New York: UNDP.
Vernooy R 2003. Seeds that Give Participatory Plant Breeding. Published by International Development Research Centre http://www.idrc.ca/seeds.

Windfuhr M 2005. Food Sovereignty towards democracy in localized food systems. Discussion Paper 2005, FIAN, Germany. Published by ITDG Publishing. 